\title{
Highly Skilled Portuguese Professionals: Who Are They and What Moves Them Out of the Country? Profiles, Factors and Motivations
}

\begin{abstract}
Susana Teles Amaral
Researcher in the Interdisciplinary Centre of Social Sciences

Ana Paula Marques

Associate Professor, PhD of Sociology (University of Minho/Portugal), Senior Researcher in the Interdisciplinary Centre of Social Sciences

Abstract

In the context of the financial and social-economic crisis, Portugal has recently been the scene of massive outflow of professionals who seek/find employment alternatives in other countries. Also the young-adults most skilled are being affected by this lack of opportunities. Who they are and what moves this highly skilled population out of the country? Based on the outputs of an online inquiry applied to a wide network of these emigrants with higher education degree, we propose both the understanding of conditions - pull and push factors - as the knowledge of the characteristics, motivations, trajectories, strategies and ways of life of the emigrants ' profile.
\end{abstract}

Keywords: Emigration, highly skilled professionals, (trans)national labour markets.

\section{Introduction}

Within the context of the Portuguese economic and financial crisis, migration of highly qualified professionals (holders of higher education diplomas) are of particular focus in the context of (trans)national labour markets and feature diverse and distinctive settings compared to the recent past. Indeed, Portugal has been the scene of significant outflows of professionals who seek / find alternative employment in other countries. The young adults with higher qualifications, invisible in traditional narratives of Portuguese emigration, are now also affected by this situation of lack of opportunity and blocking to the achievement of their socio-professional aspirations, causing them to look for alternatives abroad, more attractive in terms of wage and career development. This is an increasingly marked tendency, but whose contours are yet to be clarified.

Representing about $10 \%$ of the total migration, the population with higher qualifications is increasingly implicated in these flows, presenting the greatest increase in the last decade: 87. 5\% (PIRES et al., 2014, p. 69). The significant increase of the qualifications and expectations of Portuguese assets is bottlenecked in the national labour market, still based on a pattern of traditional production less innovative business/organizational models that hinder the

Competitiveness of the economy, leading to disqualifying processes and waste of human capital. In addition, the privileged means to administer this manpower have been increasing apparent job insecurity traits (eg contracts of limited duration, low wages, and lack of labour rights). Therefore, there is a greater exposure to job insecurity, (the risk of) unemployment and the suspension or postponement of more consistent familiar/personal/professional projects (MARQUES, 2010a; $2010 \mathrm{~b}$ ). Who are they and what causes this high qualified people to move abroad? From the responses to an online survey made in 2014/15 to Portuguese assets with higher education degree, living abroad, we propose a qualitative analysis of the phenomenon. In this analysis, priority is given to either understanding the constraints - both the attraction towards a new destiny and the repulsion for the original place - and the characteristics, motivations, trajectories, strategies and ways of life of migrants' profile ${ }^{1}$.

\footnotetext{
1 This presentation is based on an ongoing PhD project, titled "Opportunities' crisis and new settings of Portuguese emigration: the case of highly skilled professionals" (EmiPaq), financed by FCT (SFRH / BD / 84107 / 2012).
} 
We start by making a brief theme framework, emphasizing the available statistical information, although scarce. Secondly, we focus on descriptive analysis of the results of the survey made to a sample of the actors involved in these processes highly skilled professionals currently residing outside of Portugal - who left the country before and after 2011, a critical year associated with the crisis that marks the start of the country's external financial aid. We will present their socio-demographic profile, their professional career (pre and post departure), the migratory path, the relationship with the country of origin, the dynamics of integration in the host country, their projects and prospects for the future, as well as any constraints to their achievement and an evaluation of the emigration experience. We analyse also the individual and structural constraints that influenced the output in its dimensions of attraction/repulsion. From this analysis, we resumed the overall research objective: understanding the reconfiguration of the latest emigration of Portuguese graduates, emphasizing what brings together and / or distinguishes these agents and migration processes from the previous qualified transnational mobility emerging in the years $80 / 90$, due to the internationalization of our economy and mobility's incentive policies, with particular emphasis on the development programs of intra-European academic mobility, as well as the degree of approximation of the factors that constrain it in relation to traditional "determinants" of the Portuguese structural emigration1.

In short, in this article we aim to update the sociological knowledge on the topic of emigration, focusing the analysis on highly qualified professionals; the evolution of their motivations / constraints; the modalities and processes of such mobility, as well as their expectations and perspectives. This way, we intend to comprehend potential future implications for the process of economic recovery and development. This analysis, still preliminary, suggests that there are geographical, social and economic imbalances that influence the phenomenon in question, simultaneously supported by social predispositions internalized and incorporated into individuals' lifestyles throughout history, as well as support networks that drive and facilitate its implementation. The joint analysis of structures with the one of the logic and strategies of the actors involved in these processes allows a better understanding of the phenomenon, placing it in the heterogeneity and complexity of contemporary transnational professional mobility. Based on this analysis, one relocates the centrality of work and achievement and personal and professional development as well as the recent transformations of the professional (trans)national markets and the fundamental dimensions of these professional mobility dynamics, in what becomes a starting point for future deepening of the investigation.

\section{Framework - the (un)available information}

The figures on migration are scarce, scattered and incomplete. Still, it is possible to make approximations to the volume and direction of the current flows ${ }^{2}$.

With a $21 \%$ emigration rate, Portugal was in 2010 the 12 th country in the world with the most emigrants and the first among the countries of the European Union (considering only countries with over one million inhabitants).

The Portuguese emigrated population has grown more than the population living in Portugal ( $18 \%$ vs. $7 \%$, respectively, between 1990 and 2010). Although they have decreased with the onset of the international crisis (2008), the country departures started to increase exponentially from 2011 onwards $^{3}$. Since that year, at least 285,000 Portuguese emigrated (2011-80,000; 2012-95,000; 2013-110,000).

The Portuguese emigration is predominantly European. The UK is now the main country of destination, followed by Switzerland, Germany and Spain. The United Kingdom is also the main destiny to professionals with higher qualifications. The (lack of balance between high rates of emigration and low rates of immigration ${ }^{4}$, places Portugal as a repulsion country within the European migratory context.

\footnotetext{
${ }^{1}$ Regarding this topic, see ALMEIDA \& BARRETO, 1976; SERRÃO, 1977 and GODINHO, 1978.

2 The data presented throughout this chapter may be consulted at:

http://www.observatorioemigracao.secomunidades.pt/np4/?newsld=3924\&fileName=OEm_EmigracaoPortuguesa2014_RelatorioEst.pdf

3 This indicator reflects the asymmetric impact of the financial crisis and the recovery time on the different countries that were initially affected. Ireland, Spain, Greece and Portugal are among the countries where the emigration rate went up and the immigration rate fell down.

4 Throughout the last 2 decades, research has gone massively towards to the immigration studies (see ROCHA-TRINDADE, 1993; GUIBENTIF, 1996; BAGANHA, 1996; PEIXOTO \& IORI, 2011), analyzing the entrance flow in our country and giving little to no importance to the departures that still endured, especially from 2002 onwards. The most recent data points out to a clear decrease in the immigration rates to Portugal (see OCDE; INE; MATEUS, 2015).
} 
Regarding more qualitative aspects - characteristics of those who exit the country and their profiles -, there is little we know about. We can confirm that the current Portuguese emigration is the most qualified: the group with the most growth between 2000 and 2011 is the one composed by people with a high degree diploma (jumped from $6 \%$ to $10 \%$ ). The data suggests that this $87 \%$ growth is accompanied by the growth in the qualifications of the general population over the last decades. The Employment Survey made by the INE (National Statistics Institute) reinforces this tendency to a higher qualified emigration, across all the higher education degrees, even PhDs (CARDOSO, 2012, p. 63). The emigrants' distribution per genre is almost even, although there are more men (52\%) than women (48\%). With regard to other qualitative info (e. $\mathrm{g}$. profession, field of study, civil state, home town in Portugal) the data is still scarce ${ }^{1}$.

\section{Our sample: an approximation to an emerging profile}

The results presented here come from the application of an online survey to a convenience sample of 304 graduates with a higher education degree residing outside of Portugal. The application, which took place between May and December 2014, was addressed to a prior contacts network from universe in analysis, which was then extended by sharing and referring to new potential respondents. Taking into account the nature and quantity of information used, it is important to note that we cannot face the presented data as estimated absolute values. The objective of this research is, given the shortage / lack of alternative sources of qualitative information, to function as an indicator of the trends in evolution on this phenomenon.

Although the number of responses is not statistically significant, the monitoring of the available data revealed that have reached saturation of the information. On the other hand, this sample, though random, reflects a number of trends that are beginning to be perceived on other studies with the same universe, at least when one is taking into account the basic variables ${ }^{2}$.

\section{Sociodemographic profile}

This sample is well balanced with regard to the gender of respondents: $52,6 \%$ masculine ( $n=160$ ) and $47,4 \%$ feminine $(n=144)$, being on the line with the aforementioned growing feminization of this kind of emigration, preceded by the exponential growth of the women participation in the Higher Education Institutions ${ }^{3}$.

With regard to age, this is a very heterogeneous group, as intended. Our respondents have between 22 and 60 years old, marking two symbolic moments: the entrance and the exit from the labor market. However, the average age stands at 34 . 4 years, with almost $75 \%$ of cases being between 26 and 40 years old (73. 5\%), and are thus in the prime of their working lives and implementing potential family building projects.

Table 1: Age

\begin{tabular}{|l|l|l|l|l|l|l|}
\hline & N & Missing & Minimum & Maximum & Mean & Std. Deviation \\
\hline What is your ag? & 304 & 2 & 22 & 60 & 34,44 & 7,79 \\
\hline
\end{tabular}

Source: Online survey - project EmiPaq

More than $50 \%$ were single at the time of the interview, $40.4 \%$ are married or living in de facto unions, some of which have initiated the relationship and began to cohabit already out of Portugal after the exit. However, the majority $(70.1 \%)$, has no children and only $28.9 \%$ emigrated accompanied by the nuclear family.

\begin{tabular}{|ll|l|l|}
\hline Table 2: Marital status & N & $\%$ \\
\hline & Single & 165 & $54,3 \%$ \\
& Married & 94 & $30,9 \%$ \\
& Divorced & 15 & $4,9 \%$ \\
What is your current marital status? & De facto union & 29 & $9,5 \%$ \\
& Widowed & 1 & $0,3 \%$ \\
& Total & 304 & $100,0 \%$ \\
\hline
\end{tabular}

\footnotetext{
1 João Teixeira Lopes' work (2014) is one of the few already available.

2 Reference to the work developed by the Emigration Watch.

${ }^{3}$ Source: statistics of DGEEC/MEC and PORDATA
} 


\section{Source: Online survey - project EmiPaq}

Before leaving Portugal, our respondents inhabited mainly in the North, and most of them in Porto $(37,8 \%)$. However, $1 / 4$ of our sample came from Lisbon $(24,1 \%)$, which shows us a strongly urbanized and coastal migration model. On the one hand, this type of emigration (coastal, urbanized) distances itself from the previous ones; on the other hand, the North is still the area where the most people depart from and that is a structural feature throughout History, mainly due to country's development model and the region's labour market configuration. Nonetheless, one cannot forget that the process of sample building started in this region, with some possible bias arising from it.

Regarding the education level, and given that the conclusion of a higher degree was an obligatory condition to participate in our survey, all the respondents have at least concluded a degree in a Higher Education Institution, mainly Bachelors $(39,5 \%)$ and Masters (36,8\%). It should be noted the presence of $53 \mathrm{PhDs}(17.4 \%)$ which, in the national context, it is also significant giving the national average ${ }^{1}$.

Table 3: Education

\begin{tabular}{|c|c|c|c|}
\hline & & $N$ & $\%$ \\
\hline \multirow{5}{*}{$\begin{array}{l}\text { What is the highest education level you } \\
\text { attained? }\end{array}$} & Bachelors & 120 & $39,5 \%$ \\
\hline & Masters & 112 & $36,8 \%$ \\
\hline & PhD & 53 & $17,4 \%$ \\
\hline & Others (Post-graduation; MBA; ...) & 19 & $6,3 \%$ \\
\hline & Total & 304 & $100,0 \%$ \\
\hline
\end{tabular}

Source: Online survey - project EmiPaq

The field of engineering and technologies is the most represented, with $34,5 \%(\mathrm{~N}=105)$. Within this field, it should be highlighted the Civil Engineering ( $N=20)$, the Computer Engineering $(N=18)$, the IT Engineers $(N=15)$ and Mechanical Engineering $(\mathrm{N}=10)$. The Social Sciences have also a top position $(28,9 \%)$, not due to being an area traditionally associated with migration flows as much as it is due to the majority of the surveyed in this subgroup have a diploma in Education Professors Training ( $\mathrm{N}=20)$, Economics $(\mathrm{N}=14)$, International Relations $(\mathrm{N}=8)$ and Journalism $(\mathrm{N}=7)$. In the remaining areas to be noted, we have Nursing ( $N=17)$ and Architecture $(\mathrm{N}=16)$, degrees only recently associated with a difficulty to find jobs in the country, as well as areas as Biology $(\mathrm{N}=22)$ and Biochemistry $(\mathrm{N}=13)$.

Table 4: Academic field of study

\begin{tabular}{|c|c|c|c|}
\hline & & $\mathrm{N}$ & $\%$ \\
\hline \multirow{7}{*}{ Degree's field of study ${ }^{2}$} & Hard and Natural Sciences & 49 & $16,1 \%$ \\
\hline & Engineering and Technology Sciences & 105 & $34,5 \%$ \\
\hline & Health Sciences & 33 & $10,9 \%$ \\
\hline & Agrarian Sciences & 0 & $0,0 \%$ \\
\hline & Social Sciences & 88 & $28,9 \%$ \\
\hline & Humanities & 29 & $9,5 \%$ \\
\hline & Total & 304 & $100,0 \%$ \\
\hline
\end{tabular}

Source: Online survey - project EmiPaq

It is also noteworthy the weight of the participation in academic mobility programs in our sample. In fact, $37.5 \%$ had one or more experiences of studying abroad before engaging in a professional transnational mobility, and more than $75 \%$ through ERASMUS, a major program of intra-European academic mobility.

\section{Job status before emigration}

\footnotetext{
${ }^{1}$ According to some PORDATA's data, based on DGEEC/MEC statistics, in 2013 the individuals who concluded their PhD's accounted for $4,4 \%$ of all the higher education graduates. In previous years, this percentage was even lower.

2 The structure and coding system used is the "Classificação de Domínios Científicos e Tecnológicos (FOS), 2007.
} 
The employment status before emigrating is one of the most striking variables of this analysis.

Contrary to what is conveyed in the media and political discourses ${ }^{1}$, unemployment does not appear as the main direct cause of the emigration of highly qualified youngsters.

In fact, the percentage of those who claim to be unemployed or looking for the 1st job at the time of their exit from Portugal does not reach the $20 \%(\mathrm{~N}=60)$. The vast majority was in a seemingly stable job situation by having a full-time job (43. $8 \%$ ) and a long-term contract ( $\mathrm{N}=92)$. The sectors of activity of these professionals were varied, but were mainly Education (19. 4\%), Health and Social Work (13. 8\%), Manufacturing Industries, Construction and Financial activities, with about 10\% each.

\section{Current job status}

If we compare the previous job situation with the current, lived in the host country, there is an improvement towards greater stability, suitability of the profession to the area of academic training and career development. In this sense, only $2 \%$ are looking for a new job, and of the 259 that are working, 163 have a long-term contract, which becomes important if we consider that most of our sample went out very recently, as we shall see later. Regarding the activity sector, the distribution is very similar to the previous one, being noteworthy the increased representation of construction and scientific research.

When asked ${ }^{2}$ about the aspects that contribute most positively to differentiate their current job status when comparing their situation to the general Portuguese reality, our respondents considered their current situation to be much more favourable. The wages come, arguably (79. 1\%), as the trump card of foreign labour markets compared to the Portuguese. The two other differentiating aspects for over $50 \%$ of respondents are the working conditions and expectations of career progress.

\section{Graphic 1: Current situation's most positive aspects}

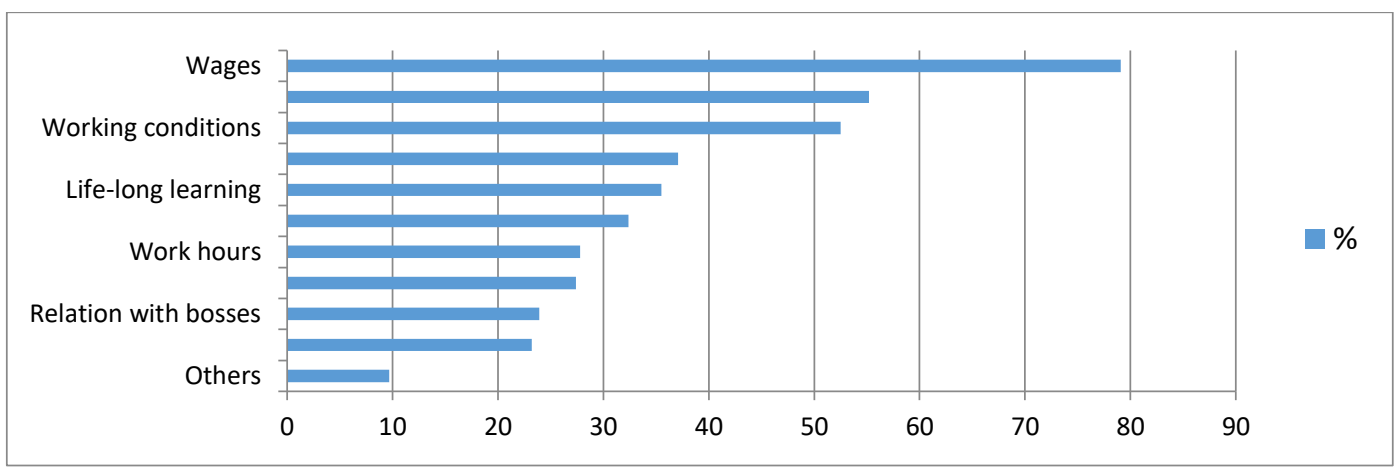

Source: Online survey - project EmiPaq

\section{Migratory path}

For the majority of respondents (76. $6 \%$ ) this is the first emigration experience. For those who already have some migratory history, the main destinations were Spain $(N=18)$, UK $(N=12)$, Lusophone Africa Countries $(N=14), U S A(N=9)$ and France $(\mathrm{N}=8)$, and some have tried multiple destinations $(\mathrm{N}=15)$.

For the current residence countries, Europe is the principal receptor of our surveyed $(70 \%)$, in line with the general Portuguese emigration profile. The country with the largest representation is the United Kingdom $(N=96)$, in line with the data available to the universe of professional graduates residing outside Portugal (PIRES, 2014). Spain comes in second position, but with a considerably lower number $(\mathrm{N}=37)$. Despite the crisis has dramatically decreased the number of Portuguese immigrating to this country, with regard to highly skilled emigration, the major Spanish metropolitan areas

\footnotetext{
1 In the project's exploratory stage, we analyzed the focus (political, corporative, institutional and academic) of several actors involved in the public debate around the current emigration wave. We did it by taking a look at the discourses made in media and exploratory interviews made to insiders. A part of that work may be consulted in AMARAL \& MARQUES, 2014.

2 This question was responded only by the 259 individuals working in the host country's labor market.
} 
continue to be attractive hubs, especially in the fields of ICT, financial activities and research. Like the trend already noted by other ongoing studies, in which Germany has emerged as a destination for the most qualified, particularly for engineering, in this sample 19 respondents are residing / working in this country. More traditional destinations for Portuguese emigration are also present in our sample, although with less weight. France $(N=14)$ and Switzerland $(N=10)$ are the most frequent, particularly in the areas of health and social work, partly as a result of social/familiar networks family that facilitate a socio-professional integration in these contexts ${ }^{1}$.

Considering the remaining destinations, the Lusophone Africa Countries are the main receivers of these professionals, led by Angola ( $N=22)$, but with the presence of other former Portuguese colonies, such as East Timor $(N=16)$, Brazil $(N=$ 15) and more residually, Sao Tome and Principe, Mozambique, Macau and Cape Verde. The cases of Angola and Brazil reflect the numbers that are available to the universe and the visibility assumed by these two countries, especially with regard to the area of construction. The case of East Timor is more specific, generally populated by seconded teachers.

The emigration date plays a very important role in this analysis as an independent variable, being related directly with the overall goal of the ongoing research: understanding the reconfiguration of the latest emigration of Portuguese graduates, stressing what approaches and/or differs them from previous migration waves. For this analysis we consider two distinct groups: those who left the country before and after 2011, a critical year associated with the crisis that marks the beginning of the application of restrictive measures under the Economic Adjustment Programme. This division will be key later, in particular for the analysis of the factors/reasons for the exit. Thus, it can be seen that most left Portugal after the beginning of $2011(66.8 \%$ ) and the number of respondents who left in 2011 almost doubled when compared to previous years and continued to grow until 2014. 2013 is the year that registers a stronger emigration flow (22. 4\%), as happened for all Portuguese emigration, regardless of their education level.

Table 5: Emigration year

\begin{tabular}{|ll|l|l|}
\hline & & N & $\%$ \\
\hline \multirow{3}{*}{ YEAR } & $<2010$ & 101 & $33,2 \%$ \\
& $>2011$ & 203 & $66,8 \%$ \\
& Total & 304 & $100,0 \%$ \\
\hline
\end{tabular}

Source: Online survey - project EmiPaq

To the question "have you emigrated alone?", $62.8 \%$ responded positively. However, the number of individuals who went out accompanied by the nuclear family is also significant (28. 9\%), given the average age of respondents and the percentage of those who were married/in a de facto union (about 40\%). This information suggests to us that for these 88 respondents the emigration was less an experience or a temporary response to the crisis and more of a family project.

Reasons/motivations for the exit

The reasons / factors that influenced the decision to migrate are mostly of a professional nature. For almost $50 \%$ of our sample, the possibility to practice something in their field of study, and under more favourable conditions, is the main driver of output. There are also other noteworthy reasons, such as the economic (21. 1\%) and academic (19. 4\%). Later we will see how this order of reasons / factors relates to the outgoing year.

Table 6: reasons/ factors on the basis of the emigration

\begin{tabular}{|ll|l|l|}
\hline & Academic & $\%$ \\
\hline & Personal/Affective & 59 & $19,4 \%$ \\
& Economic & 23 & $7,6 \%$ \\
Familiar & 64 & $21,1 \%$ \\
Which were the main reasons for you to & Professional & 7 & $2,3 \%$ \\
emigrate? & Various & 145 & $47,7 \%$ \\
& Missing & 4 & $1,3 \%$ \\
& Other (cultural,... ) & 1 & $0,3 \%$ \\
& Total & & $0,3 \%$ \\
& & & $100,0 \%$ \\
\hline
\end{tabular}

Source: Online survey - project EmiPaq

${ }^{1}$ Regarding the French case, see LOPES, 2014. 
To the question "To which extent these reasons influenced your decision to exit the country?"1 the established order of influence by respondents was structured as follows:

1. Possibility for personal development (mean $=4.15)$

2. Seeking new experiences and challenges, adventure $($ mean $=4.00)$

3. Better working conditions in the host country (mean $=3.79)$

4. Investment in an international career (mean $=3.74$ )

5. Prospects for career advancement in the host country (mean $=3.74$ )

6. Income, wage differences (mean $=3.67$ )

7. Lack of future prospects in Portugal (mean $=3.65$ )

8. Will to emigrate/desire to leave the country (mean $=3.48$ )

9. Socio-economic situation of Portugal (mean $=3.45$ )

10. Recognition/appreciation of their occupation in the host country (mean $=3.32$ )

11. Cosmopolitanism, transnational and multicultural environment of the host country (mean $=3.22$ )

12. Contractual security in the current job (mean $=2.62$ )

13. Emancipation/economic independence $($ mean $=2.07)$

14. Economic difficulties (mean $=1.83$ )

15. Being in a precarious situation (mean $=1.72$ )

16. New business opportunities (mean $=1.42$ )

17. Difficulty in finding the 1 st employment (average $=1,39$ )

18. Being unemployed before emigrating (mean $=1.38$ )

19. Being together with his/her partner (mean $=1.34$ )

20. Strategy of internationalization of the company (mean $=1.13$ )

21. Distancing from personal problems $($ mean $=0.99)$

22. Being with the family (mean $=0.95)$

The pull factors of the destination countries are clearly prevalent in the decision to leave the country, particularly with regard to individual motivations of investment in career development as well as structural conditions of labour markets in the host country. With regard to the country of origin's repulsion factors, the socio-economic context is gaining importance, especially regarding the "lack of future prospects. " More than the weight of an unattractive present, our respondents justify their decision with a certain disbelief and hopelessness in a positive change on the current situation, anticipating it as lasting and not as much as cyclical. This perception will influence their prospects for the future, as we shall see.

In short, this analysis show up two types of reasons / motivations that influenced the departure from Portugal: on the one hand, ego-centred motivations, closely linked to a personal development and growth, the desire for change, to experience new adventures and get to know different realities; On the other hand, the attractiveness of cross-border labour markets if the numbers are high, it is also due to the demand that exists on the part of the host countries and can be explained, in part, by the recognition of these professionals' skills.

Interestingly, the reasons most frequently mentioned by common sense and around which a public debate has been fuelled, have very little significance in this analysis. We refer to "be in a precarious situation" (mean $=1.72$ ); "New business opportunities (mean =1. 42); "Trouble finding the 1st job" (mean = 1, 39); "Being unemployed before emigrating" (mean = 1. 38). Also economic-related aspects, such as economic difficulties (mean $=1.83$ ) and emancipation / economic independence (mean $=2.07$ ) have less weight than we would expect. Still, we emphasize that there are gender differences and other differences related to the time of departure (before / after 2011) regarding these indicators. When developing the model for analysis and construction of the theoretical framework these aspects will be problematized and will be object of a theoretical deepening.

Following the above analysis, it is no surprise that we found that the majority (68.8\%) assume the departure as an individual option, a rational choice, given the possibility of embracing more favourable alternatives to their personal and professional development and also assuming an anticipation of the calculated risk of an unpromising near future in the national context.

Table 7: Departure type

${ }_{1}$ Scale used: 0=Do not apply; $1=$ Did not influence; $2=$ Influenced little ; $3=$ Influenced moderately; 4=Influenced; $5=$ Influenced a lot 


\begin{tabular}{|c|l|l|}
\hline & $N$ & $\%$ \\
\hline An individual option & 209 & $68,8 \%$ \\
Influenced by a third part, though & 39 & $12,8 \%$ \\
voluntary & 52 & $17,1 \%$ \\
Do you consider that your departure was: Forced by the social and economic \\
context \\
Imposed by others (undesired)
\end{tabular}

Source: Online survey - project EmiPaq

\section{Emigration's project preparation}

Holders of an academic and social capital above the average, most migration projects were preceded by a period of planning and consideration, which could be the cause of a higher rate of success and permanence of this migration profile compared to less qualified, subjected to a greater risk and lack of ponderation.

Table 8: Planning

\begin{tabular}{|ll|l|l|}
\hline & $N$ & $\%$ \\
\hline & Highly planned & 34 & $11,2 \%$ \\
& Very planned & 81 & $26,6 \%$ \\
Do you consider your emigration project & Reasonably planned & 124 & $40,8 \%$ \\
to have been: & Lowly planned & 52 & $17,1 \%$ \\
& Nothing planned & 13 & $4,3 \%$ \\
& Total & 304 & $100,0 \%$ \\
\hline
\end{tabular}

Source: Online survey - project EmiPaq

The different resources available online, along with a network of contacts already stabilized in host countries are the most used means at this stage of decision-making and planning. Almost $50 \%$ of our sample resorted either to job sites, sites about the countries, etc., or personal contacts abroad to prepare the migration project. On the contrary, we highlight the weak use of various public services, including the consulates, as well as the specialized services from recruitment companies, despite their growing presence in the national recruitment market ${ }^{1}$.

\section{Graphic 2: Means used to obtain previous info on the emigration conditions and the host country}

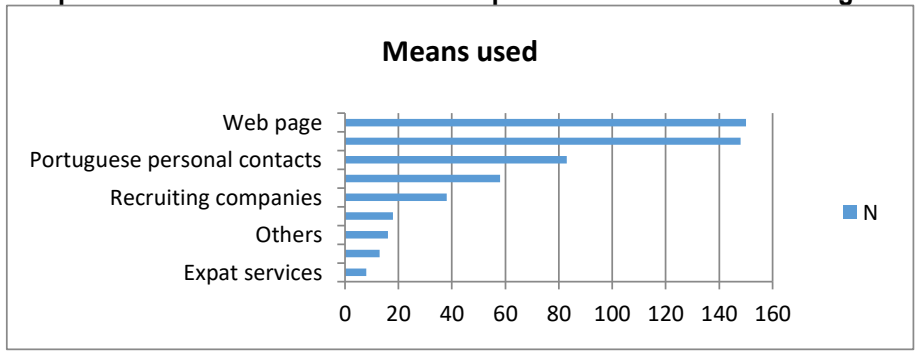

Source: Online survey - project EmiPaq

One of the clearest manifestations of this process prior to departure is that the vast majority emigrate with a job already contracted $(65.8 \%)$. Only $5 \%$ took more than three months to be able to insert itself in the labour market. 1 One has to note, here, the frequency of recruiting/selection initiatives to trans(national) markets directed mainly towards the Health and
Engineering sectors. 
Table 9: 1st job in the host country - waiting time

\begin{tabular}{|c|c|c|c|}
\hline & & $\mathrm{N}$ & $\%$ \\
\hline \multirow{10}{*}{$\begin{array}{l}\text { After departing, how many months it took for you } \\
\text { to land your } 1 \text { st job? }\end{array}$} & Job was already contracted & 200 & $65,8 \%$ \\
\hline & $0-1$ months & 33 & $10,9 \%$ \\
\hline & 2-3 months & 13 & $4,3 \%$ \\
\hline & 4-5 months & 4 & $1,3 \%$ \\
\hline & 6-12 months & 8 & $2,6 \%$ \\
\hline & More than 12 months & 4 & $1,3 \%$ \\
\hline & Missing & 8 & $2,6 \%$ \\
\hline & Left country to study & 31 & $10,2 \%$ \\
\hline & Haven't seeked any job & 3 & $1,0 \%$ \\
\hline & Total & 304 & $100,0 \%$ \\
\hline
\end{tabular}

Source: Online de survey - project EmiPaq

\section{Relation with departure country - links maintained with Portugal}

In general, these Portuguese continue to maintain close contact with their country of origin, either by traveling or maintaining frequent contact (telephone, internet, social networking, and skype). The most common are two visits per year to Portugal, which, in most cases, will coincide with Christmas and the summer holidays. However, those vary greatly according to distance from the country of residence and family ties that still remain in Portugal.

Table 10: Visits to Portugal per year

\begin{tabular}{|c|c|}
\hline $\begin{array}{ll}\mathrm{N} & \text { Valid } \\
\text { Mean } & \text { Missing } \\
\text { Median } & \\
\text { Mode } & \\
\text { Standard Deviation } \\
\text { Minimum } & \\
\text { Maximum } & \\
\end{array}$ & $\begin{array}{l}304 \\
0 \\
4,60 \\
3,00 \\
2 \\
6,38 \\
0 \\
50\end{array}$ \\
\hline
\end{tabular}

Source: Online survey - project EmiPaq

If we look at other indicators featured in previous flows such as money sent to Portugal and participation in Portuguese associations wherever they live, the relationship with Portugal is being eased: the majority does not send regularly part of their income (60.2\%), and the participation in organized groups of fellow citizens in local host is even lower (19. 1\%, mainly recreational meetings and activities). This does not mean that there aren't other Portuguese at their workplaces and residence, with almost $75 \%$ admitting they live near Portuguese themselves (only $17.9 \%$ say conviviality is rare), which reinforces the evidence of the strong Portuguese presence and concentration in the host countries for these professionals.

Table 11: conviviality with other Portuguese

\begin{tabular}{|ll|l|l|}
\hline & $N$ & $\%$ \\
\hline & Permanently & 63 & $28,3 \%$ \\
& Very frequently & 71 & $31,8 \%$ \\
& Frequently & 47 & $21,1 \%$ \\
If you DO meet with other Portuguese & Not frequently & 40 & $17,9 \%$ \\
people, how often it happens: & Nul & 0 & $0,0 \%$ \\
& Missing & 2 & $0,9 \%$ \\
& Total & 223 & $100,0 \%$ \\
\hline
\end{tabular}

Source: Online survey - project EmiPaq 


\section{Relation with host country - integration dynamics}

The housing situation is stable, following the home leasing model, usual for the local population, particularly with regard to European countries. Only about $15 \%$ have more temporary situations (leased room, family/friend's house or hotel room).

Table 12: Housing situation

\begin{tabular}{|c|c|c|c|}
\hline & & $\mathrm{N}$ & $\%$ \\
\hline \multirow{8}{*}{$\begin{array}{l}\text { What is your current housing } \\
\text { situation? }\end{array}$} & Own house & 20 & $6,6 \%$ \\
\hline & Rented house & 187 & $61,5 \%$ \\
\hline & Company's provided house & 48 & $15,8 \%$ \\
\hline & Rented room & 40 & $13,2 \%$ \\
\hline & Hotel room & 4 & $1,3 \%$ \\
\hline & Family/friend's house & 4 & $1,3 \%$ \\
\hline & 999 & 1 & $0,3 \%$ \\
\hline & Total & 304 & $100,0 \%$ \\
\hline
\end{tabular}

Source: Online survey - project EmiPaq

The self-assessment that the respondents make of their integration process in the host country is clearly positive (global integration - mean $=3.63$ ), especially in regard to the occupational dimension (mean $=4.22$ ). To the question "what do you consider to be your degree of integration in your host country with respect to professional dimension", $85.2 \%$ assumed to be very high or high.

\section{Graphic 3: Professional integration}

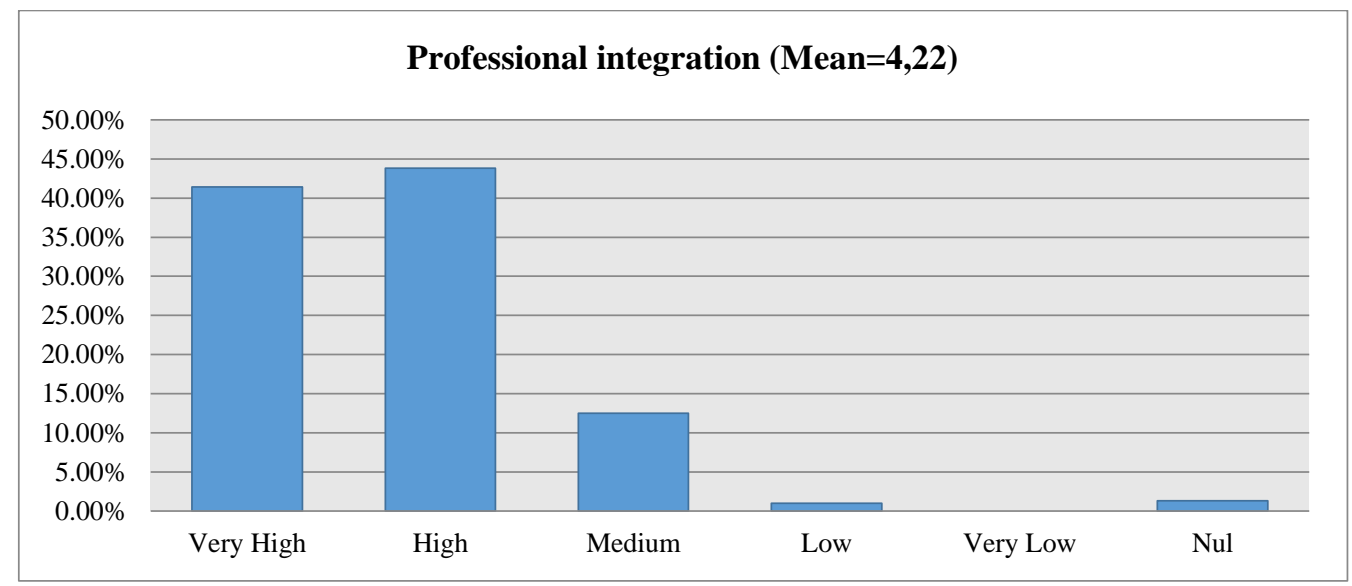

Source: Online survey - project EmiPaq

Also social integration is evaluated very positively (mean $=3.57$ ), and only $8.6 \%$ have a low or very low degree. This dimension, along with the cultural and affective dimensions, constitute distinctive aspects compared to the classical dynamics of the Portuguese structural emigration, with low levels of engagement with the society and culture of the host countries, creating distinct and closed residential and associative spaces. 


\section{Graphic 4: Social integration}

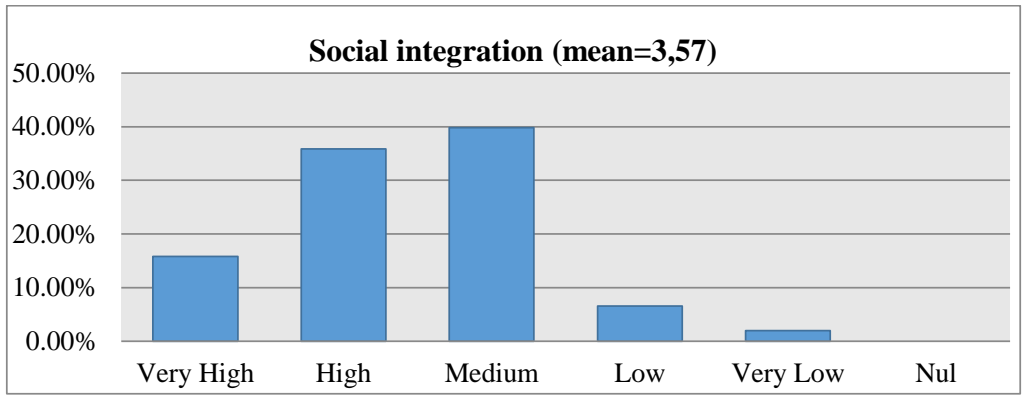

Source: Online survey - project EmiPaq

Graphic 5: cultural-ludic integration

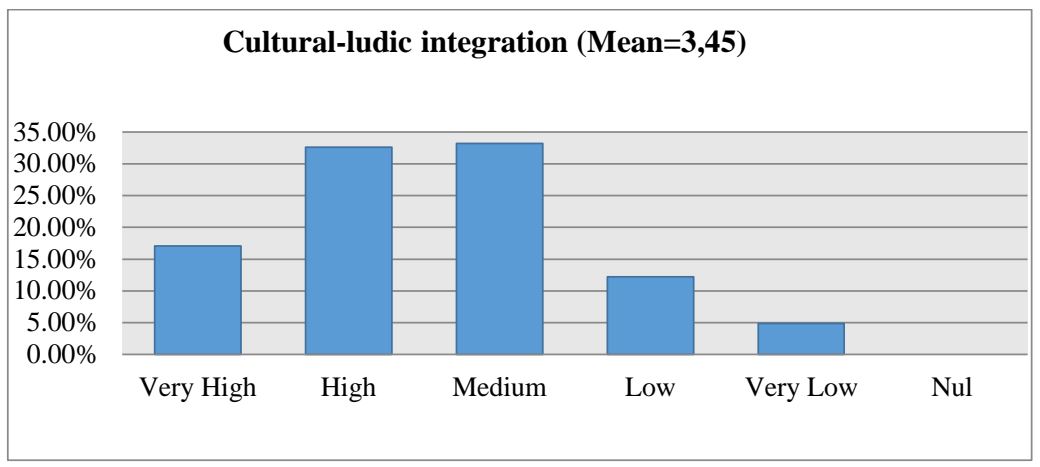

Source: Online survey - project EmiPaq

\section{Graphic 6: Affective integration}

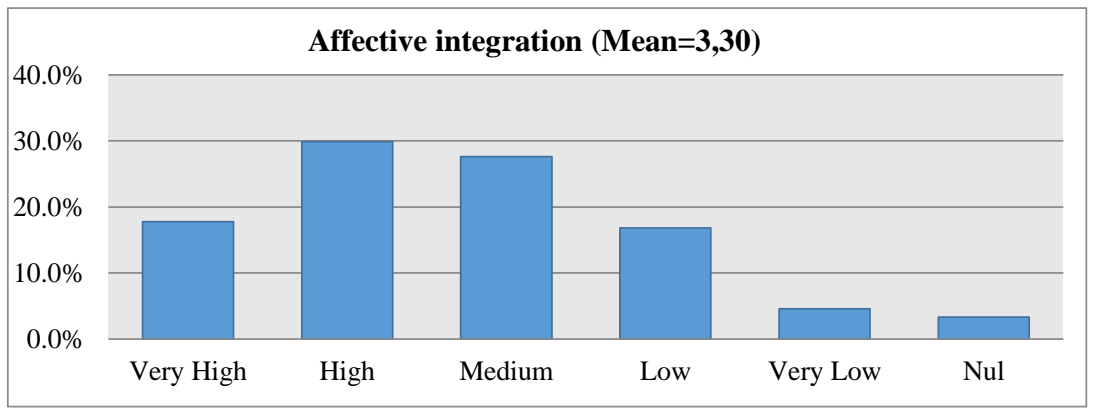

Source: Online survey - project EmiPaq

\section{Expectations towards the future}

The fact that the majority of respondents have a recent and short history of emigration may explain the significant unpredictability rate $(28 \%)$ and Do Not Know $(17.1 \%)$ responses when asked about the predicted length of stay in the country. However, it should be noted that only $9.5 \%$ plan to change their place of residence after two years, though not meaning they will be back to the country of origin. 
Table 13: Length of stay

\begin{tabular}{|c|c|c|c|}
\hline & & $\mathrm{N}$ & $\%$ \\
\hline \multirow{9}{*}{$\begin{array}{l}\text { What is your prediction regarding the length of stay in your } \\
\text { current country of residence? }\end{array}$} & Not known / unpredictable & 85 & $28,0 \%$ \\
\hline & Forever & 10 & $3,3 \%$ \\
\hline & Don't know & 52 & $17,1 \%$ \\
\hline & Less than 1 year & 4 & $1,3 \%$ \\
\hline & $1-2$ years & 25 & $8,2 \%$ \\
\hline & $3-4$ years & 46 & $15,1 \%$ \\
\hline & $5-10$ years & 69 & $22,7 \%$ \\
\hline & More than 10 years & 13 & $4,3 \%$ \\
\hline & Total & 304 & $100,0 \%$ \\
\hline
\end{tabular}

Source: Online survey - project EmiPaq

In fact, only $14.1 \%$ predicts the return to Portugal to happen in the next five years, as it goes against the most common predominance of return intentions in these recent emigration situations, where the roots in the host country are still weak and the desire to return is maintained. On the contrary, the vast majority intend to stay in the same country or align with the commonly called "flow of outstanding skills (or brains)," while planning to continue to seek new and more attractive destinations to live and work.

Table 14: Predictions for the next 5 years

\begin{tabular}{|c|c|c|c|}
\hline & & $\mathrm{N}$ & $\%$ \\
\hline \multirow{7}{*}{$\begin{array}{l}\text { In the next } 5 \text { years you predict } \\
\text { to: }\end{array}$} & Remain in your current country & 132 & $43,4 \%$ \\
\hline & Return to Portugal & 43 & $14,1 \%$ \\
\hline & To live in both countries, alternatively & 30 & $9,9 \%$ \\
\hline & Go to another country, closer to Portugal & 26 & $8,6 \%$ \\
\hline & Go to another country, regardless of the distance to Portugal & 58 & $19,1 \%$ \\
\hline & Do not know & & \\
\hline & Total & 304 & $100,0 \%$ \\
\hline
\end{tabular}

Source: Online survey - project EmiPaq

When asked about the real possibility of return to Portugal, whether they wish it or not, almost $70 \%$ admit that within five years they will not yet be prepared to do it. However, compared with previous responses, we noticed that some of those who yearn to return assume that is not possible to accomplish it - or a possible context favourable to the return may not match the desire to return. 
Table 15: Return possibility

\begin{tabular}{|ll|l|l|}
\hline & & $N$ & $\%$ \\
\hline & Yes & 94 & $30,9 \%$ \\
Do you consider that within 5 years you will have the conditions, if wanted, to return definitely to & No & 210 & $69,1 \%$ \\
$\begin{array}{l}\text { Portugal? } \\
\text { Total }\end{array}$ & 304 & $100,0 \%$ \\
\hline
\end{tabular}

Souce: Online survey - project EmiPaq

As to the reasons for a possible anticipation of the return, most cannot position themselves, despite the professional factors representing about $25 \%$. Though the familiar and affective dimensions (not being present, nostalgia) are the most mentioned as a negative aspect, on the qualitative assessment of migratory experience its weight as a return lever is not significant (12. 5\%). The centrality and appreciation of the work to this professionals is a very significant aspect to the detriment of other dimensions of life ${ }^{1}$. The ease of communication with the country of origin by the widespread use of new media (internet, mobile phone) as well as cheap, faster plane travel, will lessen the distance to Portugal. This perception will be object of further development.

Table 16: reasons to return to Portugal

\begin{tabular}{|ll|l|l|}
\hline & N & $\%$ \\
\hline & Familiar, Affective & 38 & $12,5 \%$ \\
& Socioeconomics & 51 & $16,8 \%$ \\
& Professionals & 75 & $24,7 \%$ \\
& Socio-politics & 20 & $6,6 \%$ \\
Which reasons could play an important & None & 12 & $3,9 \%$ \\
factor in an earlier return to Portugal? & Others & 8 & $2,6 \%$ \\
& Do not know & 99 & $32,6 \%$ \\
& Several & 1 & $0,3 \%$ \\
& Total & 304 & $100,0 \%$ \\
\hline
\end{tabular}

Source: Online survey - project EmiPaq

\section{Self-concept}

One of the frequent theoretical discussions around this highly qualified professional profile that leaves the country lies on the very appropriateness / legitimacy of the use of the term "emigrant" to define him, particularly with regard to intraEuropean mobility. Despite this continuing to be the formal concept to denote nationals residing in a foreign country, regardless of qualification, the socio-professional status or the destination country, only $11.8 \%$ of respondents consider themselves emigrants. The definitions with which most identify are "Portuguese living abroad" (32. 9\%) and "world citizen" (29. 9\%). With some surprise, we found that most current and sophisticated terms like "expatriate" or "professional mobility" are less referenced. This dimension will deserve a theoretical deepening and an empirical approach in future interviews ${ }^{2}$.

Table 17: Self-concept

\begin{tabular}{|c|c|c|c|}
\hline & & $\mathrm{N}$ & $\%$ \\
\hline \multirow{4}{*}{$\begin{array}{l}\text { Which of these expressions would better } \\
\text { describe your current situation? }\end{array}$} & Expat & 35 & $11,5 \%$ \\
\hline & Emigrant & 36 & $11,8 \%$ \\
\hline & World citizen & 91 & $29,9 \%$ \\
\hline & Portuguese living abroad & 100 & $32,9 \%$ \\
\hline
\end{tabular}

\footnotetext{
1 The importance of the professional domain gets highlighted when we analyze the most positive aspects of the migratory experience. In an open-question, expressions such as "work", "professionals", "career", "conditions", "opportunities", "experience", "perspective", and "wage" were the most frequent words. This domain is also important when thinking about coming back to the country of origin, due to the fact that the majority of these emigrants will only accept a comeback whenever the working conditions are similar at home.

2 The next step in the project will be the deepening of the main analytical dimensions, through semi-structured interviews to a sample representative of the main profiles we encountered.
} 


\begin{tabular}{|l|l|l|}
\hline Professional on the move & 33 & $10,9 \%$ \\
European & 1 & $0,3 \%$ \\
Migrant within the EU & 1 & $0,3 \%$ \\
Dual Citizenship & 1 & $0,3 \%$ \\
Portuguese citizen on the move & 1 & $0,3 \%$ \\
European citizen & 1 & $0,3 \%$ \\
Don't know & 4 & $1,3 \%$ \\
Total & 304 & $100,0 \%$ \\
\hline
\end{tabular}

Source: Online survey - project EmiPaq

\section{In sun: Clues to the research's development}

Resuming the driving issues of this research - pre and post crisis' outlines and the approach/distinction towards a "classic" emigration as a structural phenomenon - we will end this article by presenting some tips, suggested by the previous descriptive analysis, for future research developments.

First, it should be noted the profiles' diversity/heterogeneity (socio-demographic, academic, professional), as well as the diversity of paths and destinies of this high qualified migrants, especially those part of the wave that left the country after the outbreak of the financial crisis and its subsequent socio-economic effects.

It is noteworthy, too, the increasing feminization of this migration profile, and the fact that the women in our sample have motivations and aspirations similar to those of their male counterparts. However, their working conditions on departure are generally more precarious and unfavourable than those of the surveyed men, a difference that will be attenuated along the migratory path, on the host countries, suggesting that gender inequalities are still a harsh reality in the Portuguese labour market.

One of the aspects that is most evident in this analysis is the continuing centrality of work, career and professional fulfilment in the life projects of the respondents. The emigration project presupposes a reorganization of social and personal life in the host country, where they work and feel fulfilled professionally, having little confidence or investment in a return in the short term. The (trans)national labour market positions itself as a regulator of this type of mobility, as it happens with the traditional labour migration, although in this case the departure from Portugal is set as a strategic response to certain economic aspirations and needs of specific professions, fuelled by an international competition for working among the "best". The current emigration of the most qualified reiterates, therefore, its position as a "structural constant of the Portuguese economy" (GODINHO, 1978), an "international movement of workers", based on global geo-economic imbalances; a 'latent possibility "which is realized when the international context is favourable (BAGANHA \& GÓIS, 1999, p. 232).

Despite the importance, evident in this analysis, of the ego-centred reasons/ motivations as a decision to leave, the position occupied by the national economy in the international division of labour, the specific dynamics of employment, unemployment and insecurity, as well as the more subjective dimensions of labour relations in the Portuguese context ${ }^{1}$ cannot be separated from this "will" to seek new experiences and opportunities ${ }^{2}$. In this sense, the reconfiguration of the development model and of the Portuguese labour market is presented as the path, slow but inevitable, to mitigate future departures, making Portugal more attractive, whether for domestic or for foreign professionals to perspective our country (again) as a possibility.

\footnotetext{
1 To a deeper understanding on the topic, see PINTO, 2006.

2 It should be noted that, when crossing data of the reasons to emigrate with the year of departure, the push factors associated with the Portuguese socioeconomic context or the lack of a future perspective have higher values to those who departed after 2011.
} 


\section{References}

[1] ALMEIDA, Carlos; BARRETO, António. Capitalismo e Emigração em Portugal. Lisbon: Prelo Editora, 1976.

[2] AMARAL, S. ; MARQUES, A. P. Emigração Portuguesa de Profissionais de Saúde: (Di)Visões em torno de um fenómeno emergente. In: MARTINS, M. I. C. ; MARQUES, A. P. ; COSTA, N. R. ; MATOS, A. (Orgs. ). Trabalho em Saúde, Desigualdades e Políticas Públicas. CICS/ENSP/FIOCRUZ, 2014. p. 141-158. Available:

[3] http://www. lasics. uminho. pt/ojs/index. php/cics_ebooks/issue/current

[4] BAGANHA, M. I. ; GÓIS, P. Migrações Internacionais de e para Portugal: o que sabemos e para onde vamos?. Revista Crítica de Ciências Sociais, Coimbra: CES, n 52/53, Vinte anos de teoria social, p. 229-280, 1998/99.

[5] BAGANHA, M. I. Immigrants Insertion in the Informal Market. Deviant Behaviour and the Insertion in the Receiving Country, $1^{\circ}$ Relatório, Coimbra: CES, 1996.

[6] CARDOSO, J. L. (Coord. ). Empregabilidade e Ensino Superior em Portugal, Estudos e Relatórios 1, Lisbon: ICS, 2012.

[7] GODINHO, V. M. L'emigration portugaise (XV-XX Siécles): une constante structurale et les réponses auX changements du monde. Revista de História Económica e Social, I, p. 5-32, 1978.

[8] GUIBENTIF, P. Le Portugal face à l'immigration. Revue Européenne des Migrations Internationales, 12(1), p. 121-139, 1996.

[9] INE - Instituto Nacional de Estatística. Available: https://www. ine. pt

[10] LOPES, João Teixeira (Org. ). Geração Europa? Um estudo sobre a jovem emigração qualificada para França. Lisbon: Editora Mundos Sociais, 2014.

[11] MARQUES, A. P. 'Sacralização' do mercado de trabalho: Jovens diplomados sob o signo da precariedade. Configurações, 7, p. 65-89, 2010a.

[12] MARQUES, Ana Paula; Alves, M. G. Inserção profissional de graduados em Portugal, (Re)configurações teóricas e empíricas. V. N. Famalicão: Edições Húmus, 2010b.

[13] MATEUS, Augusto (Coord. ). Três décadas de Portugal europeu: balanço e perspetivas. Lisbon: Fundação Francisco Manuel dos Santos e Sociedade de Consultores Augusto Mateus \& Associados, 2015.

[14] OCDE. International Migration Outlook 2014. OCDE Publishing, 2014. Available: http://dx. doi. org/10. 1787/migr_outlook-2014

[15] PEIXOTO, João; lori, Juliana. Crise, Imigração e Mercado de Trabalho em Portugal - Retorno, Regulação ou Resistência?. Parede: Ed. Principia, 2011.

[16] PINTO, J. M. Precarização e relações de sentido no espaço social do trabalho. Revista Sociologia, (offprint), Porto: Faculdade de Letras da Universidade do Porto, vol. 16, p. 177-190, 2006.

[17] PIRES, R. P. (Coord.); PEREIRA, C. ; AZEVEDO, J. ; RIBEIRO, A. C. Emigração portuguesa: relatório estatístico. Observatório da Emigração \& Rede Migra, Centro de Investigação e Estudos de Sociologia (CIES -IUL), Instituto Universitário de Lisboa (ISCTE -IUL), Direção-Geral dos Assuntos Consulares e das Comunidades Portuguesas (DGACCP). 2014

[18] PORDATA - Base de Dados Portugal Contemporâneo. Fundação Francisco Manuel dos Santos. Available: http://www. pordata. pt/

[19] ROCHA-TRINDADE, Maria Beatriz. Migrações e multiculturalismo. In: Secretariado coordenador dos programas de educação multicultural (ed). Escola e sociedade multicultural. Lisbon: Ministério da Educação. p. 65-73. 1993

[20] SERÃO, Joel. A emigração portuguesa - sondagem histórica. Lisbon: Livros Horizonte. 1977. 